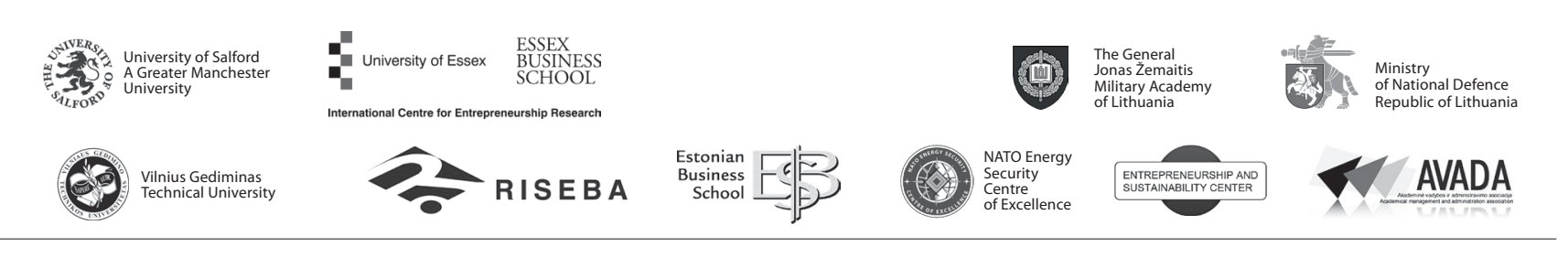

\author{
JOURNAL OF SECURITY AND SUSTAINABILITY ISSUES \\ ISSN 2029-7017 print/ISSN 2029-7025 online \\ 2018 September Volume 8 Number 1 \\ https://doi.org/10.9770/jssi.2018.8.1(7)
}

\title{
EVALUATIONS OF SECURITY MEASURES: THE PECULIARITIES OF THE APPLICATION OF MEDIATION IN THE AREA OF RESOLVING CRIMINAL LEGAL CONFLICTS
}

\author{
Nikolajs Jefimovs \\ Daugavpils University, Vienibas Str. 13, LV-5401, Daugavpils, Latvia \\ E-mail: nikolajs.jefimovs@du.lv
}

Received 20 January 2018; accepted 15 May 2018

\begin{abstract}
The alternative methods of dispute resolution are new field of study in Latvia. In most cases procedurial issues of these methods and their real practical application are outside any legal regulation. One of these alternative dispute resolution methods is called mediation. Person, who is responsible for the management of this process, is called mediator. The meaning of this term is known from the ancient civilization times. It is useful to understand the initial comprehension of mediation in order to sucessfully implement this process in the legal system of modern society. Nevertheless the elaboration of mediation procedure asks serious evalution of possibilites in order to completely evolve basic principles of alternative dispute resolution methods in the legal system of any country. Answering on question whether it is possible to completely realize the concept of mediation, it is necessary clearly understand, what it is and how you can use the advantages of this process in real life. Application of mediation in the Latvian criminal law obeys to the special requirements and depends on certain circumstances.
\end{abstract}

Keywords: security; mediation; State Probation Service; mediation subjects; conflict settlement; Latvia

Reference to this paper should be made as follows: Jefimovs, N. 2018. Evaluations of security measures: the peculiarities of the application of mediation in the area of resolving criminal legal conflicts, Journal of Security and Sustainability Issues 8(1): 79-86.

https://doi.org/10.9770/jssi.2018.8.1(7)

JEL Codes: K10, K14, K40

\section{Introduction}

The criminal-law conflict is closely linked to a wide range of variations in the usage of mediation: agreement between the victim and the offender on the settlement of a conflict with the participation of a third neutral party, without any participation of law enforcement agencies; agreement between the victim and the offender on the settlement of the conflict during the preliminary stage of the pre-trial investigation; agreement between the victim and the offender on the settlement of the conflict in the procedural stage of court proceedings; agreement between the victim and the offender on the settlement of the conflict at the procedural stage of the execution of the trial decision; conciliation between the parties of the dispute with legally binding consequences, if the dispute complies with the conditions, prescribed by law, for the termination of criminal proceedings and reconciliation has been achieved because of participation of State Probation Service mediator or with the participation of state authority. In the author's opinion, in majoriy of cases it is more effective to use mediation variations, than to apply traditional litigation in the area of criminal dispute resolution (e.g. Jurkevičius, Bublienè 2017; Ardalan et al. 2017; Šišulák 2017; Limba, Šidlauskas 2018; Kordík, Kurilovská 2018; Lietuvnikè et al. 2018). 
Analyzing the scope of the term "mediation" regarding the area of the resolution of criminal disputes in the Republic of Latvia, it is necessary to mention, that one and the same term can be defined differently, for example, depending on the background knowledge of the parties of dispute, depending on the purpose to be achieved, depending on the area, in which mediation has been used, etc. The Mediation Law (The Mediation Law 2014) passed by the Latvian Parliament on May 22nd, 2014, does not provide a sufficient clarity about how, according to the legislator, term „mediation" could be defined in the area of resolution of criminal disputes. The legal regulation of mediation in the field of public law could not be found in the other regulatory enactments of Latvia. At the same time, some Latvian researchers (Judins 2005; Luksa 2012) doctrinely define mediation in the area of resolving criminal matters as a victim and offender conciliation (Jefimovs 2017). However, it would be wrong to perceive the concept of mediation in the field of public law too broadly or vice versa, too narrowly, merely as a victim and offender conciliation in the criminal proceedings.

For the correct formulation of the concept of mediation in the area of resolving criminal conflicts it is necessary to define and take into account all the features, that reflect the qualitative characteristics of this term. Moreover, defining the meaning of mediation in the field of public law, it helps to clarify the content of the concept, highlighting the general and specific features of the term. That helps to distinguish between the research object and other similar concepts, and it helps to draw conclusions about its specific place in the content of similar concepts. The term "mediation in the area of resolving criminal legal disputes" in international law means any process, involving the victim and the offender of the criminal offense, who, freely and without any influence, agree to eliminate the problems, caused by a criminal dispute, acting with the help of a neutral third party (mediator) (Recommendation No. R (99) 19 of the Committee of Ministers to member States concerning mediation in penal matters 1999). Making research of mediation in the area of resolving criminal legal issues in Latvia, it is necessary to analyze a question of the current mechanism for applying mediation in the area of public law and what needs to be improved in the mediation process for the facilitation of its wider and more effective use.

\section{Settlement as a legal institute}

Currently legal regulation of Latvia isn't proposing an application of mediation in criminal disputes (Tamberga 2014). However, the laws passed in recent years point to the existence of separate elements of mediation in Latvian criminal law. For example, since 1999 Latvian criminal law proposes the settlement between a victim and an offender, which is the basis for the release of a person from criminal responsibility; since 2004, the Law on the State Probation Service defines an amicable settlement with an intermediary; the institute of conflict settlement is also defined in the Criminal Procedure Law (Judins 2005). The qualification requirements for subjects, organizing an amicable settlement, are specified in the Regulation of Cabinet of Ministers No.782 (adopted 20 November 2007) „The procedure, by which the State Probation Service certifies voluntary probation officers, who are intermediaries in a settlement" (Regulation of Cabinet of Ministers No.782 "The procedure, by which the State Probation Service certifies voluntary probation officers, who are intermediaries in a settlement" 2007) the arrangements for organizing a settlement process are included in the State Probation Service Law (State Probation Service Law 2004).

The philosophy of the institute of settlement is based on the restorative justice theory. A. Judins (2005) in the scientific paper "Settlement in the Latvian Criminal Law" points out, that restorative justice is a process, in which the offender, the victim and other interested parties agree on how to eliminate the consequences of the crime. He points out, that restorative justice give an opportunity to offender, victim and public (society) to participate in the liquidation of the consequences of crime. In the author's view, the connection between restorative justice and mediation in the area of criminal dispute settlement is expressed in an objective way between the victim, the offender and the third neutral side - in the mediation process, in turn, the objective interaction of the parties is based on the restorative justice.

For the purpose of the effective implementation of restorative justice in the Latvian public law the law maker had to propose an implementation of the mediation process for the resolution of criminal disputes (Zahars, 
Stivrenieks 2016). At this stage, the core ideas of the concept of restorative justice had to be adopted (TeivānsTreinovskis, Amosova 2016): paying more attention to the negative consequences of crime, which is equally harmful to victim, offender and state. Another element of the concept of restorative justice is an inclusion of a wider range of subjects in the process of elimination of the consequences of crime. In the author's opinion, the basic principles of the concept of restorative justice have been introduced in the Latvian public law system: national legislation provides an alternative process for the resolution of criminal legal proceedings through the participation of a neutral party; the process takes into account opinions of victim and offender on possibilities of conflict ending; dispute parties make an agreemt on the terms of conflict resolution.

\section{Settlement with participation of intermediary}

State Probation Service Law defines settlement as a process of negotiations in which the victim and probation client shall participate and in which the help of intermediary shall be used, in order to rectify the consequences of a criminal offence and to reach a settlement between a victim and a probation client (Section 1, Paragraph 2) (State Probation Service Law 2004). Despite the fact that mediation is not mentioned in the legal definition of an amicable settlement, the connection between mediation and settlement is obvious. The definition of settlement includes several features, that are similar both to settlement and mediation:

- an alternative conflict resolution process;

- victim, offender and third neutral person participate in the process;

- neutral person helps to agree on resolution of the dispute.

Latvian researchers also point on the connection between mediation and settlement. For example, A. Judins (2005) points out, that during the settlement procedure individuals seeks to reach an agreement on negative consequences of ciminal offence through mediation. J. Bartulis in the publication "Settlement as an alternative" describes the nuances of application of the settlement, which corresponds to the features of mediation: an opportunity to optionally resolve a conflict, participation of two persons - victim and offender, process is organized and managed by the third neutral person. M. Luksa (2012) in the article "Settlement as a substitute of litigation" defines the institute of settlement as a voluntary negotiation process between victim and offender, which is run by a neutral person - an intermediary, who helps the parties to agree on a mutually acceptable solution. Later in the article the term "mediation" is used instead of the term settlement". It is necessary to agree, that institutes of settlement and mediation are objectively similar, they are based on the same principles. At the same time it should be noted, that these institutes are not identical, because mediation is a broader concept, than settlement.

Mediation is a general process of conflict resolution, which is implemented between two parties of dispute, under the management of the third neutral person, that results to the resoltuion of the conflict. Process of mediation aren't regulated by any legal act (Brown 2002). Its main purpose is to restore relationships between parties of conflict. E. Uotila and S. Sambu (2010) point out, that the main benefit of mediation is a possibility of rebuilding people's relationships. D. R. Froyd (2014) in the article "California Court-Connected Mediation: Appreciating the Influence of Power and Processes" points out, that the mediation process helps to achieve mutually supportive elements in the relationships between parties of dispute. A. Eye, E. Mun and P. Mair (2009) in the article "What Carries a Mediation Process? Configural Analysis of Mediation" points out, that the use of mediation helps to achieve a harmony in the relationships between parties of dispute. A. Judins (2005) expresses a similar view, pointing out, that the agreement between parties of dispute, achieved by the usage of mediation, is a significant social result. Reconciliation means, that conflict, caused by the violation of law, has been resolved and the person, who has been harmed, has received a moral and / or material compensation. The author agrees with the opinions of the above-mentioned researchers. Through mediation parties of dispute renew their human relationships. In turn, changes in a legal status, due to the use of mediation, may not occur. Legal acts may not give any legally binding meaning to the fact of mediation application. In the Criminal law principle of legal regulation "only permitted by law" is in effect (Neimanis 2004). In a case, if the use of mediation is not permitted in the legal provisions, the fact of its applicaton will not have any legal consequences. Legal consequences of the application of mediation arise only, if the relevant legal regulation proposes condi- 
tions for its application. In the Latvian legal system such a type of binding mediation is designated by the term "settlement". Professor V. Liholaja (2009) from the University of Latvia points out, that application of settlement has legally binding consequences for the parties of dispute (Liholaja 2009). A. Judin suggests a similar assumption. He expresses an opinion, that the Latvian Criminal Procedure law takes into account only the result of settlement, rather than its procedure. K. Strada (2001) in the article "About an agreement in the Criminal Procedure Law" states, that settlement could be the basis for termination of any criminal case, if a guilty person has committed a specific criminal offense. It can be concluded, that application of settlement always has a legally binding effect. Comparing the mediation consequences and the consequences of the application of settlement, it is clear, that the institute of settlement is narrower, than the content of mediation.

\section{Control of mediator acitivities}

The State Probation Service organizes control and training of intermediaries, who perform alternative criminal dispute resolution operations. Since mediation as a dispute resolution process is a broader concept than settlement, notion of the term "mediator" in the mediation process and in the settlement process differs. In the scientific literature, the requirements for the qualification of mediators usually aren't named. Researchers tend to focus on the personality and character of the mediator. For example, S. J. Imperati and S. M. Maser (2014) focuses on the personal characteristics of the mediator ("act as an actor") to organize, lead and persuade dispute parties to agree on conflict resolution conditions. K. Kressel (2013) as one of the main criteria of professionalism of mediators determines the intuition, developed for high-level professionals. That feature gives an opportunity to mediator effectively use the mediation process in the area of dispute resolution. Common requirements for the qualification of mediators aren't mentioned in national laws and regulations. For example, in the Republic of Lithuania the requirements for the qualification of mediators, who provide their services in the area of civil litigation, aren't defined at a national level (Mediation in Member States Lithuania 2015). At the same time in Finland these requirements are prescribed by law (Mediation in Member States - Finland 2015). Also, in Latvia, with the adoption of the Mediation Law, these legal relationships are regulated by legal norms. Taking into account, that legal scope of the term "mediator" is related with the institute of mediation, for the purposes of connection of the mediator with the institute "settlement" the term "intermediary" has been defined.

\section{The role of the State Probation Service in the mediation process}

An intermediary in mediation is an official of State Probation Service, who organizes and conducts a settlement process, or a volunteer, who is trained and certified to organize and manage a settlement process (Section 1, Clause 8 of the State Probation Service Law) (State Probation Service Law 2004). It means, that settlement could be organized and managed by the State Probation Service official or by a service-certified volunteer.

In the legal theory of Western law meaning of the State Probation Service and its authorities differs. H. Wood and G. Brown (2014) associate probation service competencies in the UK with the help of mentally disabled persons, who commited crimes. M. Dooris (2013) links the probation service's competence with the improvement of health of violators and with other improvement measures . R. Hek (2012) examines probation service from the positions of social services and preventive measures. He emphasizes a crucial role of organizing a cooperation between the probation service, the police and students, who are planning to pursue a career in law enforcement agencies. J. L. Johnson (2014) pays more attention to the functions of the probation service in area of institutions of deprivation of liberty, monitoring the behavior of convicts, as well as controlling recently released individuāls. The Eastern researchers have the same opinion on the probation service, that doesn't differ significantly from opinion of their Western counterparts. For example, russian scientist E. S. Rakhmaev (2009) points out, that the establishment of a probation service is based on the idea of a forced supervision of convicts, with the aim of controlling how a convict fulfills court imposed obligations, how is corrected behavior of a convict, how the convict is re-socialized and adapted to normal life. E. N. Shatankova (2008) pays more attention to the preventive nature of functions, performed by the probation service. S. P. Kubancev (2006) points out, that the probation service is a method of social rehabilitation of convicts and persons, released from 
imprisonment, without any penalty components. Similarly, the opinions of Latvian researchers about the scope of the functions, performed by the probation service, do not differ significantly (Zahars 2012).

This correlates with the fact, that establishment of the probation service was based on ideas of the 19th century about voluntary, philanthropic and, to a certain extent, religious, approach to the conviction of the criminals (Forbes 2010). An analysis of the current situation regarding the functions, performed by probation service, shows, that today it has transformed from an independent institution, providing social services to convicted persons, to the state-run institution, whose main purpose is to implement state policy in the fight against crime and to protect society from offenders (Smirnov, Lavrinenko, Tumalavičius 2018). E. N. Shatankova (2008) in the dissertation "Conditional conviction and probation abroad (comparative legal analysis)" points out, that the range of probation service's functions may be related to criminal penalties (for example, in Sweden), with the other criminal law's means of influence (for example, in the United Kingdom), with the release of a convicted person (for example, in Estonia), with performing of other, unspecified functions (for example, in the United States).

The legal status and authorities of the Probation Service of Latvia are regulated by the State Probation Service Law (2004). According to the law the main function of the probation service is the implementation of state policy by the execution of a criminal penalty - forced labor - and a compulsory measure of a corrective nature public work, as well as supervision of probation clients and correction of social. The law also emphasizes the place of a State Probation Service in the national institutional structure, indicating, that it is under the supervision of the Minister of Justice.

One of the authorities of State Probation Service in the field of organization of the settlement procedure in Latvia is connected with the rights to train intermediaries, who organize and manage process of settlement. A general description of this function is indicated in the informative report, prepared in 2006 "On the organization and implementation of the function of State Probation Service - the settlement between the victim and the probation client through an intermediary" (An informative report "On the organization and implementation of the function of State Probation Service - the settlement between the victim and the probation client through an intermediary" 2006). The main criteria for acquiring an intermediary's rights is the successful passing of an intermediary training program, which consists of two parts: theoretical - 28 hours and practical - at least three settlements has to be managed. Applicant also has to successfully pass a final examination (Regulation of Cabinet of Ministers No.782 "The procedure, by which the State Probation Service certifies voluntary probation officers, who are intermediaries in a settlement" 2007). All the examinations are approved by the Certification Commission, established by the State Probation Service. Intermediary authorities are granted for two years, with the rights to extend them. An applicant for participation in the study programm could be authority from the probation service or any other person, who hasn't been prosecuted for the intentional commission of a criminal offense (State Probation Service Law 2004). There are no other legal options for becoming an intermediaty in settlement.

Latvian legislator has formulated different qualification criteria for mediator position candidates. Mediation Law defines, that there are two types of mediators in Latvia: certified mediators and mediators. Requirements for applicants for the positon of a certified mediator are related with a criteria of a certain age (at least 25 years), previous education (must be at least higher education), knowledge of the state language, passing of a training program (at least 30 hours) and final examinations. Also there are requirements, related with the lack of previous punishment. Certificate of a certified mediator is issued for 5 years with the right to extend it (Regulation of Cabinet of Ministers No.433 "Certification and attestation procedure of mediators" 2014). Determining the qualification requirements for certified mediators, it is assumed, that the country must have confidence in the high professionalism of these speciālists (Luksa 2014). At the same time, Latvian legal system doesn't prevent to get a mediator's qualification for those person, who aren't meet the previously mentioned requirements. The competence of these specialists is not guaranteed at the state level. These mediators are almost alike to certified mediators. However, in the court recommended mediation, certified mediators have the advantage (The first mediator certificates will be presented 2014). 


\section{Conclusion}

Results of the research lead to a conclusion, that development of two institutes "mediation" and "settlement" occured at the same time. Mediation as an alternative dispute resolution method is not regulated with legal acts. In turn, the procedure of settlement, as well as the conditions for its use, are regulated by legal acts of the Republic of Latvia. Settlement is used to resolve certain criminal disputes. Settlement process could be organized and managed by an official of the State Probation Service, or by a volunteer, who is specially trained and certified. Such an amicable settlement has legally binding implications. However, at the same time, the mediation process can be organized by any mediator with relevant experience and knowledge. This process can be implemented by settling any criminal disputes, without legally binding implications.

\section{References}

Ardalan, F.; Almasi, N. A.; Atasheneh, M. 2017. Effects of contractor and employer's obligations in buy back contracts: case study of oil exporting country, Entrepreneurship and Sustainability Issues 5(2): 345-356. https://doi.org/10.9770/jesi.2017.5.2(13)

Brown, C. J. Facilitative Mediation: The Classic Approach Retains its Appeal. Available on the Internet: http://www.mediate.com/ articles/brownc.cfm

Dooris, M. 2013. Probation as a setting for building well-being through integrated service provision: evaluating an Offender Health Trainer service. Perspectives In Public Health Vol. 133 (4), p. 199-206, ISSN: 20131125

Eye, A.; Mun, E.; Mair, P. 2009. What Carries a Mediation Process? Configural Analysis of Mediation. Integrative Psychological \& Behavioral Science Vol. 43, Issue 3, p. 228-247, ISSN: 1932-4502

Forbes, D. 2010. Probation in Transition: A Study of the Experiences of Newly Qualified Probation Officers. Journal of Social Work Practice Vol. 24, Issue 1, p. 75-88, ISSN: 0265-0533

Froyd, D. R. California Court-Connected Mediation: Appreciating the Influence of Power and Processes. Journal of Child Custody. Jul-Sep2014, Vol. 11, Issue 3, p. 237-250, ISSN: 1537-9418

Hek, R. 2012. Is it Possible to Develop and Sustain Non-Traditional Placements? An Evaluation of the Development of Practice Learning Opportunities in Partnership with the Police and Probation Services in the West Midlands. Social Work Education Vol. 31, Issue 4, p. 512-529, ISSN: 0261-5479

Imperati, S. J.: Maser, S. M. 2014. Why Does Anyone Mediate if Mediation Risks Psychological Dissatisfaction, Extra Costs and Manipulation? Three Theories Reveal Paradoxes Resolved by Mediator Standards of Ethical Practice. Ohio State Journal on Dispute Resolution Vol. 29, Issue 2, p. 223-260, ISSN: 1046-4344

Informatīvais ziṇojums „Par Valsts probācijas dienesta funkcijas - izlīguma starp cietušo un probācijas klientu ar starpnieka palīdzību - organizēšanu un īstenošanu”. [An informative report „On the organization and implementation of the function of State Probation Service - the settlement between the victim and the probation client through an intermediary"]. Available on the Internet: http://www. tap.mk.gov.lv/doc/.../tmzino_030406_prob.doc

Jefimovs N. 2017 Towards conflicts' settlement: development of the meaning of mediation in the legal doctrine. Journal of Security and Sustainability Issues 6(4): 665-672. http://doi.org/10.9770/jssi.2017.6.4(11)

Johnson, J. L. Federal Post-Conviction Supervision Outcomes: Arrests and Revocations. Federal Probation. 2014, Vol. 78, Issue 1, p. 1-12, ISSN: 0014-9128

Judins, A. Izlīgums Latvijas Krimināltiesībās. [Settlement in the Latvian Criminal Law]. Available on the Internet: http://www.probacija.lv/page.php?id=45

Jurkevičius, V.; Bublienė, R. 2017. Towards sustainable business relationships: ratification doctrine in the case of unauthorised agency, Entrepreneurship and Sustainability Issues 5(1): 72-90. https://doi.org/10.9770/jesi.2017.5.1(6)

Kordík, M.; Kurilovská, L. 2018. Intra group compliance agreement as a tool to manage the risks in the daughter companies, Entrepreneurship and Sustainability Issues 5(4): 1008-1019. https://doi.org/10.9770/jesi.2018.5.4(21)

Kressel, K. 2013. How Do Mediators Decide What to Do? Implicit Schemas of Practice and Mediator Decisionmaking. Ohio State Journal on Dispute Resolution Vol. 28, Issue 3, p. 709-735, ISSN: 1046-4344 
Kubancev, S. P. Primenenije probacii i dosrocnogo osvobozdenija ot otbitija nakazanija v vide lisenija svobodi v SSHA. [Application of probation and preliminary release from serving a sentence of imprisonment in the United States]. Zurnal rossijskogo prava, 2006, № 1, p.121

Kunitsyna, N.; Britchenko, I.; Kunitsyn, I. 2018. Reputational risks, value of losses and financial sustainability of commercial banks, Entrepreneurship and Sustainability Issues 5(4): 943-955. https://doi.org/10.9770/jesi.2018.5.4(17)

Latvijas Republikas likums "Mediācijas likums". [The Mediation Law]. Available on the Internet: http://ikumi.lv/doc.php?id=266615

Lietuvnikė, M. M.; Vasilis Vasiliauskas, A.; Vasilienè-Vasiliauskienė, V.; Sabaitytė, J. 2018. Peculiarities of illegal immigrant's intrusions into road freight transport units in the France - UK corridor, Entrepreneurship and Sustainability Issues 5(3): 634-647. https://doi. org/10.9770/jesi.2018.5.3(16)

Liholaja, V. Izlīgums un taisnīgs krimināltiesisko attiecību noregulējums. [Settlement and a fair resolution of criminal conflict]. Jurista vārds, 7th July 2009, Nr. 27 (570).

Limba, T.; Šidlauskas, A. 2018. Peculiarities of anonymous comments' management: a case study of Lithuanian news portals, Entrepreneurship and Sustainability Issues 5(4): 875-889. https://doi.org/10.9770/jesi.2018.5.4(12)

Luksa, M. Izstrādāta kārtība, kā kḷūt par sertificētu mediatoru. [Developed procedures for becoming a certified mediator]. Available on the Internet: http://m.lvportals.lv/likumi-prakse.php?id=264362

Luksa, M. Tiesāšanās vietā - izlīgums. Kā taisnīguma atjaunošanas iespēja. [In the place of court - settlement. How to restore justice]. Available on the Internet: http://www.lvportals.lv/print.php?id=247648

Mediation in Member States - Finland. Available on the Internet: https://e-justice.europa.eu/content_mediation_in_member_states-64FI-en.do?clang=en

Mediation in Member States - Lithuania. Available on the Internet: https://e-justice.europa.eu/content_mediation_in_member_states64-1t-en.do?member=1

Ministru kabineta noteikumi Nr.433 „Mediatoru sertifikācijas un atestācijas kārtība”. [Regulation of Cabinet of Ministers No.433 „Certification and attestation procedure of mediators”]. Available on the Internet: http://likumi.lv/ta/id/268136-mediatoru-sertifikacijas-un-atestacijas-kartiba

Ministru kabineta noteikumi Nr.782 „Kārtība, kādā Valsts probācijas dienests sertificē brīvprātīgos probācijas darbiniekus, kuri ir starpnieki izlīgumā”. [Regulation of Cabinet of Ministers No.782 „The procedure, by which the State Probation Service certifies voluntary probation officers, who are intermediaries in a settlement"]. Available on the Internet: http://likumi.lv/doc.php?id=166680

Neimanis, J. Ievads tiesībās. [Introduction to the law]. Rīga, 2004, p.115, ISBN 9984-97770-0-5

Rahmaev, E. S. Sluzbe probacii bitj. [The probation service must be]. Celovek: prestuplenije i nakazanije, 2009, № 3, p.29

Recommendation No. R (99) 19 of the Committee of Ministers to member States concerning mediation in penal matters (Adopted by the Committee of Ministers on 15 September 1999 at the 679th meeting of the Ministers=92 Deputies). Available on the Internet: http:// www.restorativejustice.org/legislative-assembly/15statutes-cases-regulations-and-recommendations-from-national-regional-and-intergovernmental-bodies/copy_of_europe/r99

Shatankova, E. N. Uslovnoje osuzdenije i probacija za rubezom (sravnitelno-pravovoj analiz). [Conditional conviction and probation abroad (comparative legal analysis)]. Avtoreferat dissertacija kand. jurid. nauk, Moskva, 2008, p.13-14

Smirnov, A., Lavrinenko, O., Tumalavičius, V. 2018. Analysis of social-economic security of administrative areas in latvian municipalities. Journal of Security and Sustainability Issues 7(4): 817-829. http://doi.org/10.9770/jssi.2018.7.4(17)

Strada, K. Par vienošanos kriminālprocesuālajā likumdošanā. [About an agreement in the Criminal procedure law]. Jurista vārds, 10th April 2001, Nr. 11 (204)

Šišulák, S. 2017. Userfocus - tool for criminality control of social networks at both the local and international level, Entrepreneurship and Sustainability Issues 5(2): 297-314. https://doi.org/10.9770/jesi.2017.5.2(10)

Tamberga, A. Mediācijas institūts. [Institute of Mediation]. Available on the Internet: http://www.tamberga.lv/index.php/lv/blogs-189/ item/195-mediacijas-instituts

Teivāns-Treinovskis, J.; Amosova, J. 2016. Some aspects of criminal environment impact on sustainable entrepreneurship activities. Entrepreneurship and Sustainability Issues 4(1): 17-24. http://dx.doi.org/10.9770/jesi.2016.4.1(2) 
Tiks pasniegti pirmie mediatoru sertifikāti. [The first mediator certificates will be presented]. Available on the Internet: http://www. juristavards.lv/zinas/265475-tiks-pasniegti-pirmie-mediatoru-sertifikati/

Uotila, E.; Sambou, S. Victim-Offender Mediation in Cases of Intimate Relationship Violence-Ideals, Attitudes, and Practices in Finland. 2010. Journal of Scandinavian Studies in Criminology \& Crime Prevention. Vol. 11, Issue 2, p. 189-207, ISSN: 1404-3858

Valsts probācijas dienesta likums. [State Probation Service Law]. Available on the Internet: https://likumi.lv/doc.php?id=82551

Wood, H.; Brown, G. 2014. Psychoanalytically-informed clinical supervision of staff in probation services. Psychoanalytic Psychotherapy Vol. 28, Issue 3, p. 330-344, ISSN: 0266-8734

Zahars, V. Cilvēki cietumā pārvēršas par zvēriem. [People in prison turn into beasts]. Available on the Internet: http://nra.lv/latvija/75182-vitolds-zahars-cilveki-cietuma-parversas-par-zveriem.htm

Zahars, V.; Stivrenieks, M. 2016. Security and safety enforcement: execution peculiarities. Journal of Security and Sustainability Issues 6(1):71-83. http://jssidoi.org/jssi/papers/papers/bykeyword/17

\section{About contributor:}

Nikolajs JEFIMOVS is a Lecturer, Ph.D. candidate, Head of the Department of Economics and Sociology of the Faculty of Social Sciences of Daugavpils University. Research interests: social security issues, commercial law, alternative dispute resolution methods, tort law.

ORCID ID: https://orcid.org/0000-0002-6291-6407 